\title{
Good Governance in Regional Development in Deli Serdang Regency
}

\author{
Dedy Gusman ${ }^{1}$, Muryanto Amin², Asima Yanty Sylvania Siahaan ${ }^{3}$ \\ 1,2,3 Universitas Sumatera Utara, Indonesia \\ Corresponding Author: Dedy Gusman
}

\begin{abstract}
The implementation of development must be carried out with good governance such as how the Deli Serdang Regency government applies good governance in the implementation of its development. Deli Serdang Regency has experienced rapid development in recent years, but on the other hand, corruption practices still occur and budget absorption in 2020 is still low, making this phenomenon contradictory and needs to be investigated. The purpose of this study is to analyze good governance in regional development in Deli Serdang Regency. This research uses a qualitative approach. The results of this study indicate good governance in regional development in Deli Serdang Regency as a form of development control in achieving development goals, with the principle of the rule of law as the basis for the principles of participation, transparency and accountability in development in Deli Serdang Regency. The efforts that can be done in overcoming obstacles to the application of the principles of good governance are socialization of development with the right strategy, increasing community empowerment, and increasing human resources in order to improve competence.
\end{abstract}

Keywords: Good Governance, Regional Development, Development Control

\section{INTRODUCTION}

The concept of good governance is the process of implementing state power in carrying out the provision of good services which is often called governance. Meanwhile, the best practice is called good governance. In order for good governance to become a reality and run well, it requires commitment and involvement of all parties, namely the government, the private sector and the community. Effective good governance requires good coordination and integrity, professionalism as well as a high work ethic and morale.

Robert Charlic defines good governance as managing all kinds of public affairs effectively through the making of good regulations and/or policies in order to promote community values (Santosa, 2008:130). Bintoro Tjokroamidjoj views good governance as "A form of development management, which is also referred to as development administration, which places the role of the central government as an agent of change in a developing or developing society". Efficiently and effectively by maintaining the synergy of constructive interactions between domains, the domain of the state, the private sector, and the community (Sinambela, 2008:23). According to United National Development Program, good governance is the practice of applying the authority to manage various affairs. The administration of the state politically, economically and administratively at all levels. In the concept above, there are three important pillars of good governance, namely: people's welfare (economic governance), decision-making processes (political governance), and policy implementation (administrative governance) (Prasetijo, 2009:33).

Institutions of good governance include three pillars, namely the state or 
government, the private sector or the business world and the community, which interact with each other and carry out their respective functions (Nasution, 2008:26).

The creation of a good governance or government as expected by the community requires a system that allows effective and efficient governance between the government, the private sector, and the community. Keraf and Akadun define good governance as the existence and functioning of several institutional devices in such a way as to enable the interests of the community to be properly guaranteed (Kartika et al., 2012:11).

The role of the government in creating a conducive political and legal environment, the private sector as a driver for the creation of job opportunities and community income, while the community actively participates in economic, social and political activities. The three main principles underlying the implementation of good governance are transparency, accountability, and efficiency and effectiveness. These three basic principles are universally applicable principles (Adisasmita, 2011:38). In line with this, Gambir Bhatta revealed that the main elements of governance are accountability, transparency, openness, and the rule of law coupled with management competence and human rights (human rights) (Mustafa, 2013:190).

In implementing the principles of good governance, the state is the party that has the most important role in realizing these principles. The implementation of good governance is the main prerequisite to be able to realize the aspirations of the community in achieving the goals and ideals of the nation and state. In order for this to be achieved, it is necessary to develop and implement an appropriate, clear and real accountability system. So that government administration and development can take place in an efficient, effective, clean and responsible manner and also free from corruption, collusion and nepotism.

Good governance is a discourse that accompanies the reform movement in
Indonesia. Due to the demands for the state of the government in the new order era with various problems which mainly include the concentration of power on the president, the 1945 Constitution is not functioning properly, and people who do not have the tools to express their aspirations so that they lose social control in the administration of government. The enactment of Law Number 22 of 1999 concerning regional government brought a very basic change in the system of government authority. And also the enactment of the Central and Regional Government Laws, as well as providing the basis for changes in financial matters, so that it brings overall changes in the systemic aspects of the Central Government and Regional Governments. In this new law, the principle of autonomy is complete, especially for Regency/City areas, namely, broad, real and responsible autonomy authority.

The broad autonomy authority is the area's freedom to administer the government. While real autonomy is the area's freedom to carry out its authority in the field of government, it must be based on the reality that is needed and grows, lives and develops in the area. Responsible autonomy is in the form of the realization of responsibility as a consequence of granting rights and authorities to the regions in the form of duties and obligations that must be borne by the regions in achieving the objectives of granting autonomy in the form of improving public services and welfare, developing democratic life, justice and equity. and the maintenance of harmonious relations between the center and the regions.

The demand for independent regional government management with the spirit of regional autonomy is increasingly widespread. However, the regional autonomy policy has been misunderstood by many levels of government management in the regions. Regional autonomy is understood as the freedom to manage regional resources which tends to give birth to unprofessional and uncontrolled regional governments. This is very worrying for the 
management of the local government which has the responsibility in carrying out development. This is where the concept of good governance is needed to ensure that the regional autonomy implemented in Indonesia can run properly and have a positive impact on development.

In relation to efforts to implement good governance, in this reform era, the government (Legislative and Executive) has produced three legislative products that have changed the face of the government system in Indonesia. First, Law Number 23 of 2014 concerning Regional Government, with the main focus on granting greater authority to regencies and cities in managing government and development. Second, Law Number 33 of 2004 regulates the implementation of Fiscal Balance between the Central and Regional Governments, with the main focus on the allocation of funds and greater authority to manage them to regencies/municipalities. Third, Law Number 28 of 1999 regulates the implementation of good governance, with a focus on the implementation of governance and development, both in the regions and at the center. These three laws and regulations are the basis for the concept of good governance. The implication of the presence of this Law on regional development is a shift in authority in regional planning and development policies. Through policy decentralization, regions have the authority to set policies on regional development planning and implementation.

The implementation of good governance in Indonesia is still experiencing various problems. These problems hinder Indonesia in implementing good governance. The integrity of government actors in implementing the concept of good governance is still the biggest obstacle, especially with regard to corrupt practices. Even though Indonesia is a legal country that already has a law on corruption, it does not necessarily make this country free from corruption. Every day there is news about corruption that is detrimental to the state. Good governance, which implies the freedom of a country from corruption, is not going well in Indonesia. The existing law has not been able to prevent corruption. The lack of transparency to the public also triggers corruption. Corruption does not only occur in the central government. Through the existence of regional autonomy which is the embodiment of decentralization, corruption is also rampant. Decentralization, which actually aims to improve people's welfare through equitable development, has not been carried out properly by the stakeholders in regional development.

The implementation of development must be carried out with good governance such as how the Deli Serdang Regency government applies good governance in the implementation of its development. Deli Serdang Regency has experienced rapid development in recent years, but on the other hand, corruption practices still occur and budget absorption in 2020 is still low, making this phenomenon contradictory and needs to be investigated.

A former regional secretary who was involved in the 2003 election security assistance project and the Deli Serdang Regency community development assistance project in 2004. The most recent case occurred at the Deli Serdang Regency Population and Civil Registry Office. In addition to the problem of corruption, the weak absorption of the budget by the development implementer, namely the Deli Serdang Regency Government is also a problem, such as based on the budget absorption report managed by the Development Administration Section, that the budget absorption target in the 2020 Regional Revenue and Expenditure Budget is $9.83 \%$ while the realization of budget absorption is only $1.82 \%$. Even when compared to the budget absorption in January 2019, it was greater at 2.15\%.

The implementation of good governance is the main prerequisite in realizing the aspirations of the people in order to achieve the goals and ideals of the nation and state. In this context, it is 
necessary to develop and implement precise and clear and real legal rules so that the administration of government and development can be efficient and responsible and free of corruption, collusion and nepotism. It should also be noted that there is a mechanism to regulate the rule of law in each government agency and strengthen the role and capacity of the community in having access to governance and development.

Basically, the government from the central level to the regional level as the agent for implementing government administration is entrusted with the "power" by the people to carry out government in order to realize its role as development implementer, regulator, service provider to the community and community empowerment. Therefore, the government as the party given the power should have an obligation to ensure legal certainty (Rule of Law) and a sense of justice to the community for every policy that will be taken. This requires the Deli Serdang Regency government to implement the Rule of Law principle in the implementation of its development so that the existing development in Deli Serdang meets the category of good governance. Decentralization causes the rule of law to be regulated based on the interests and needs of the community in the context of development. The rule of law is expected to stimulate participation, transparency and accountability in existing governance and development. This causes the Rule of Law to be a very important factor in the implementation of good governance in regional development.

The purpose of this study is to analyze good governance in regional development in Deli Serdang Regency.

\section{RESEARCH METHOD}

This research uses a qualitative approach. Qualitative research is the focus of attention with various methods, which include interpretive and naturalistic approaches to the subject of study
(Pandiangan et al., 2021). Qualitative research studies objects in their natural context, which seeks to understand, or interpret phenomena in terms of the meanings that humans (researchers) place on them. Qualitative research includes the use of the subjects studied and the collection of various empirical data-case studies, personal experiences, introspection, life journeys, interviews, observational texts, life journeys, interactional, and visuals-that describe the moments and meanings of everyday life and are problematic in someone's life (Pandiangan, 2015).

The object of this research is the application of the principles of good governance in the implementation of regional development in Deli Serdang Regency. According Pandiangan et al. (2018), research subjects are individuals, objects, or organisms that are used as sources of information needed for collection and research. Another term used to refer to the research subject is the respondent, namely the person who responds to a treatment given to him.

\section{Key Informants:}

1. Assistant II for the Economy and Development of the Regional Secretariat of Deli Serdang Regency.

2. Expert Staff for the Economics, Finance and Development at the Regional Secretariat of Deli Serdang Regency.

3. Secretary of Bappeda Deli Serdang Regency.

4. Head of the Regional Secretariat for the Economy of Deli Serdang Regency.

5. Head of Development Administration.

\section{Additional Informants:}

1. Community Leaders in the Field of Religion.

2. Youth Leaders.

3. Head of Environment.

4. Micro, Small and Medium Enterprises (MSMEs).

In obtaining data, techniques are needed so that it can facilitate data collection. Library research of reference 
sources is a form of research that uses library facilities by examining theoretical discussions from various books, articles, and scientific works related to writing (Pandiangan, 2018). The data collection techniques in this research are observation, in-depth interview, and literature study.

The ultimate goal of qualitative research is to describe and explain (to a certain extent) the pattern of relationships that can only be done with a certain set of conceptual analytic categories (Tobing et al., 2018). Qualitative data analysis is an effort made by working with data, organizing data, sorting it into manageable units, synthesizing it, looking for and finding patterns, discovering what is important and what is learned, and discovering what can be told to others. The three main things in these interactive models are the data reduction phase, data presentation, and conclusion drawing.

\section{RESULT}

\section{Description of Research Site}

Deli and Serdang Regencies were designated as autonomous regions in accordance with Law Number 22 of 1984 concerning the Basic Laws of Regional Government and Law Number 7 of Emergency 1965. Deli Serdang Regency's anniversary was set on July 1, 1946. Based on a Government Regulation Number 7 of 1988, the capital of the Deli Regency Government was moved from Medan City to Lubuk Pakam with an office location in Tanjung Garbus which was inaugurated by the Governor of North Sumatra on December 23, 1986.

In accordance with the issuance of Law Number 36 of 2003 dated December 18, 2003, Deli Serdang Regency has been divided into two regions, namely Deli Serdang Regency and Serdang Bedagai Regency.

Along with the continuous movement of the wheels of development, a motto was created for the Deli Serdang Regency area, in the sense of "With its people of various ethnicities, religions, races and groups uniting in Bhinnekaan in a family manner and working together to build a spirit of togetherness, explore and develop all potentials. the potential of its natural resources and human resources, thus making the strength and might to bring the Deli Serdang people to prosperity, progress, independence and always victorious throughout the ages.

\section{Vision and Mission of Deli Serdang Regency}

Deli Serdang Regency has a vision, namely: "Deli Serdang which is advanced and prosperous with its religious and harmonious community in diversity". An advanced and prosperous Deli Serdang is a district that has quality human resources, good infrastructure availability, and the fulfillment of community needs through accelerated development in all fields that are just and environmentally sound, while a religious and harmonious community in diversity makes Deli Serdang Regency whose society has a high level of firm faith and devotion to God Almighty, upholding the values and norms of harmony between religious communities, ethnic cultures and human rights.

To achieve the development vision of Deli Serdang Regency, it is carried out through missions, namely:

1. Improving quality and competitive human resources capable of increasing the benefits of science and technology.

2. Improving welfare and independence in establishing a solid economic structure based on competitive finance.

3. Improving facilities and infrastructure to support economic growth that is oriented to spatial planning policies, and is environmentally friendly.

4. Improving the order of people's lives that are religious, cultured and have good morals, based on faith in divinity and can maintain harmony, peace and order.

5. Improving the professionalism of the government apparatus to realize good 
and clean governance, which is authoritative and also responsible.

\section{Geographical Overview}

Deli Serdang Regency is one of thirty three Regencies/Cities currently in North Sumatra Province. Based on its geographical location, Deli Serdang Regency is located in the East Coast Region of North Sumatra which is directly adjacent to the Malacca Strait. Geographically, Deli Serdang Regency is located between coordinates $2^{\circ} 57^{\prime \prime}$ to $3^{\circ} 16^{\prime \prime}$ North Latitude, and $98^{\circ} 33^{\prime \prime}$ to $99^{\circ} 27^{\prime \prime}$ East Longitude. Administratively, Deli Serdang Regency consists of twenty two Subdistricts, 14 Ward and 380 Villages, with an area of 249,772 Ha $\left(2,497.72 \mathrm{Km}^{2}\right)$. The subdistrict with the largest area is Hamparan Perak District, which is 23,015 Ha or 9.21\% of the total area of Deli Serdang Regency. Meanwhile, the sub-district which has the smallest area is Deli Tua District, which is only 936 ha or $0.37 \%$ of the Deli Serdang Regency area.

\section{Good Governance in the Implementation of Development in Deli Serdang Regency}

Good governance as a concept of good governance must be implemented by taking into account the principles of good governance itself. Good governance is a demand from the community to the government to carry out good governance so that changes occur that are directed and able to prosper the community. Change can occur when there is development, in Indonesia, which has the principle of regional autonomy, has given freedom to each region in carrying out governance and development as long as there is no overlap with the central government. Through Law Number 23 of 2014 concerning Regional Government which has the main focus on granting greater authority to the Regency and City areas in managing government and development, the regions have the responsibility to carry out development that can advance the region by being oriented towards community welfare.
Implementation of development requires good governance in the process. The concept of good governance can ensure that the implementation of development carried out is in accordance with the rules and aims to serve the community. The AllIndonesian Regency Government Association, All-Indonesian City Government Association, and AllIndonesian City Council Association are of the opinion that there are 10 principles of good governance, namely:

1. Participation, in the sense that every citizen is encouraged to exercise the right to express opinions in the decisionmaking process, which concerns the interests of the community, either directly or indirectly.

2. Law enforcement, namely enforcing the law fairly for all parties without exception, upholding human rights, and paying attention to the values that live in society.

3. Transparency, namely creating mutual trust between the government and the community through the provision of information services and ensuring the ease of obtaining information and ensuring the ease of obtaining accurate and adequate information.

4. Equality, namely providing equal opportunities for every member of society to improve welfare.

5. Capability, namely increasing the sensitivity of government administrators to the aspirations of the people without exception.

6. Future insights, namely developing regions based on a clear vision and strategy and involving community members in the entire development process, so that community members are in the entire development process, so that community members have and are responsible for the progress of their area.

7. Accountability, namely increasing the accountability of decision makers in fields involving the interests of the wider community. 
8. Supervision, namely increasing supervision efforts on government and development administrators by seeking involvement of the private sector and the wider community.

9. Efficiency and effectiveness, namely ensuring the implementation of services to the community by using available resources optimally and responsibly.

10. Professionalism, increasing the ability and morale of government administrators to be able to provide easy, fast, precise and affordable services.

The realization of the concept of a wise government "good governance" is a prerequisite for achieving an effective balance in development. Good governance in regional development in Deli Serdang Regency as a form of development control in achieving development goals, with the principle of the rule of law as the basis for the principles of participation, transparency and accountability in development in Deli Serdang Regency. The minimum prerequisite for achieving good governance is the existence of the Rule of Law, participation, transparency and accountability. The four principles are a series of interrelated with each other, between one principle with another principle has an attachment. The most basic development problem is what development strategy is most likely to get a good development impact.

\section{Rule of Law as the Basis for Participation in Development Implementation in Deli Serdang Regency}

Community participation in development is an important part of development. The ideal development is development that involves the community in it. In addition to empowering the community, it also makes the community as an agent of development. Deli Serdang in carrying out development seeks in such a way as to involve the community in the implementation of development. In accordance with the mandate of Law
Number 25 of 2004 concerning National Development Planning System that people's aspirations must be adopted in development. As stated by Jeffrey Siregar, Secretary of the Deli Serdang Bappeda below: "It is certain, because the provisions of the applicable regulations, especially Law Number 25 of 2004 concerning the National Development Planning System, the aspirations of the community must be adopted by their input (the Community) because of this development, what we are doing in the regions is for the welfare of the community, listening to community complaints to be able to increase development in Deli Serdang Regency so that the level of people's per capita income can increase then automatically the regional economic growth rate will increase. But not all of the community's proposals can be implemented because they must also be adjusted to the results of investigations from the relevant agencies, whether this is indeed feasible or not, whether this is in accordance with regional development priorities and then finally adjusted to the level of regional financial capacity so there is a scale priority" (Interview, June 11, 2021).

From the information above, Deli Serdang in the implementation of development involves the community, not all of the proposals submitted by the community can be accommodated but must go through investigations from the relevant agencies to decide whether the proposed development program can be implemented or not. In addition, the redevelopment program is identified again whether the development program can be used as a priority scale considering that the development has an urgency to be implemented immediately or not. Community involvement in development in Deli Serdang is carried out in stages or in stages, where community involvement starts from the village level to the district level. 
Efforts That Must Be Done in Applying the Principles of Good Governance in the Implementation of Development in Deli Serdang Regency

The implementation of development certainly cannot be separated from the obstacles that make development not run optimally. The implementation of the principles of good governance in the implementation of development aims to ensure that the organizers of development, namely the regional government, do their job well and according to the applicable regulations, so that development is truly useful for the community.

Good governance in the perspective of development aims to review whether the implementation of development has functioned effectively and efficiently in an effort to achieve development goals. The Deli Serdang Regency Government as the local government responsible for implementing development in applying the principles of good governance needs to make efforts that are able to answer existing problems in order to carry out managed development in accordance with the principles of Good Governance.

In applying legal principles to the implementation of development, according to Jeffrey Siregar as Secretary of the Development Planning Agency at SubNational Level of Deli Serdang Regency, he stated that there were no obstacles because the implementation of development followed the corridors of statutory regulations, it was just that people did not fully understand how to prioritize development.

"There is nothing that hinders it because it is already regulated in the corridors of legislation, but sometimes these people don't understand things like that, they just want this community to have an unfounded will, sometimes they don't know which interests are more for them. community or group interests. Then also sometimes the House of Representatives recess schedule is behind our Musrenbang, now this is also an obstacle and a solution is sought where exactly they can enter this recess because sometimes it is too late so we look for loopholes before a week before the Regency Musrenbang is directed to the possibility there. Even if it is late, there is a Minister of Home Affairs Regulation Number 86 of 2017 for the preparation of the budget for the following year, if the results of the recess are left behind" (Interview, 11 June 2021).

From the answers above, in applying the legal principles, Deli Serdang Regency follows the laws and regulations. Because the implementation of development must be supervised by the House of Representatives as a representation of the people, the Deli Serdang Regency Government must really consider time in preparing the budget. The House of Representatives recess is sometimes slower than the existing Musrenbang activities so that the Deli Serdang Regency Government must wait for a response from the results of the House of Representatives Recess relating to development programs that will be carried out by the Deli Serdang Regency Government. However, there are still regulations that provide an opportunity for the Deli Serdang Regency Government to prepare a budget related to the recess in the next budget year, so that the application of legal principles is still ongoing in the implementation of development in Deli Serdang Regency.

The efforts that can be done in overcoming obstacles to the application of the principles of good governance are socialization of development with the right strategy, increasing community empowerment, and increasing human resources in order to improve competence. Socialization of development programs is important in the success of a development program. Socialization as a form of providing information to the public about the development program must have the right strategy so that development information is conveyed to the community, so that the community has a correct understanding of the development program 
delivered by the Deli Serdang Regency Government. In addition, socialization is a process of how to introduce a system to the community and how people determine their responses and reactions. The Deli Serdang Regency Government in disseminating the development program should heed at least three factors, namely: what is socialized, how to disseminate it, and who is to disseminate it.

First, what is socialized has the meaning of the form of information that will be given to the community in the form of values and roles. The Deli Serdang Regency Government can formulate in advance the information that must be conveyed to the public about the existing development implementation mechanisms in Deli Serdang Regency, such as the legal basis for the ongoing development in Deli Serdang. $\mathrm{Be}$ it in the form of legislation, ministerial regulations, or regional regulations. In order for the community to understand that the implementation of development to be carried out has a legal basis. Then it is related to how the mechanism for formulating development programs such as musrenbang from the village, sub-district to district levels must really be instilled in the community. Sources of budget funds, budget management, and limited development budgets should also be communicated to the public. Because the development budget tends to be a polemic in the midst of society. Then, as stated by the informants in this study that in carrying out development programs, Deli Serdang Regency uses a Priority Scale, namely development programs that must be implemented immediately (urgency) into priority regional development programs, after being analyzed by the relevant Regional Apparatus Organization which will responsible for carrying out the implementation of these development programs. Second, how to socialize has meaning, how the Deli Serdang district government socializes existing development programs. Both the use of media or digitalization or conventionally. The Deli
Serdang Regency Government must really analyze which way is the most effective in disseminating the development program. In the midst of the digitalization era, consideration of the use of technology media is a must, both online media and the official website of the Deli Serdang Regency government. However, it is necessary to pay attention to the use of digital media, the Deli Serdang Regency Government must provide easy access and the socialization packaging in the media is made as creative as possible so that people can easily access and are interested in understanding the existing socialization materials. Third, who will socialize, means who will socialize the development program. In conveying information, it is required to convey information that has competence and credibility. This is because the public tends to accept information that is competent and credible. The Deli Serdang Regency Government through related Regional Apparatus Organization must be able to become competent and credible providers of development information. Local Government Organizations as implementers of development programs must have superior human resources, so that people can trust and understand the socialization of existing development programs. So that the community has a sufficient understanding of the implementation of development carried out within the Deli Serdang Regency Government.

Community-centred development is very much needed at this time, making the community as the main actor in development will make development more ideal. The role of local governments as development facilitators must be able to stimulate the community to be active in development programs. Deli Serdang has indeed started to do this such as self-help in the construction of roads whose land is a grant from the community and is carried out directly by the community. This is a positive action in increasing community involvement 
in development programs organized by the Deli Serdang Regency Government.

Community empowerment efforts are also important to be considered by the Deli Serdang Regency Government in the implementation of development, especially human development. The concept of empowerment in the discourse of community development is always associated with the concept of independence, network participation, and justice and is placed on the strength of the individual and social levels. The best way to solve development problems is to foster an entrepreneurial spirit in people's lives which demands that people find new things (innovation). Community development by empowering is a design in creating stronger and healthier socio-economic conditions.

The Deli Serdang Regency Government needs to remember that the community has a lot of potential, both in terms of existing resources and from sociocultural sources. Communities have "Power" that can be extracted and channeled, which will turn into a big movement to overcome challenges in development. How to explore and utilize existing resources in the community is the core of community empowerment. In community empowerment, the most important factor is how to support the community in the position of active actors (subjects) of development, not just passive recipients. Community empowerment in development prioritizes community initiatives and creations. The role of the Deli Serdang Regency government in supporting community initiatives and creations is important in this regard. Communities who better understand the needs and problems faced must be empowered so that they better recognize their needs. The community is also trained to be able to formulate plans and carry out development independently with the government acting as a facilitator. Community empowerment in development is based on "from, by and for" the community. Community participation in implementing the development movement must be encouraged and developed gradually, and sustainably. Another effort that must be made in applying the principles of good governance in the implementation of other developments is the improvement of human resources.

\section{CONCLUSION AND SUGGESTION}

The results of this study indicate good governance in regional development in Deli Serdang Regency as a form of development control in achieving development goals, with the principle of the rule of law as the basis for the principles of participation, transparency and accountability in development in Deli Serdang Regency. The efforts that can be done in overcoming obstacles to the application of the principles of good governance are socialization of development with the right strategy, increasing community empowerment, and increasing human resources in order to improve competence.

Based on the conclusions above and also in the process of this research, the suggestions conveyed by researchers in this study are:

1. The Deli Serdang Regency Government needs to maintain and develop the implementation of good governance principles in every existing development implementation. Especially in realizing people-centered development, so that it empowers the community and makes an independent society.

2. The Deli Serdang Regency Government needs to formulate an effective socialization program for development within the Deli Serdang Regency environment. As an effort to increase community involvement in development in Deli Serdang Regency.

3. The Deli Serdang Regency Government must consistently improve the competence of human resources within the Deli Serdang Regency Government considering that the needs of the community continue to change from time to time. So that the existing human 
resources must be able to understand and implement development implementation programs that really provide positive benefits for the community in the Deli Serdang Regency Government.

\section{Acknowledgement: None}

\section{Conflict of Interest: None}

\section{Source of Funding: None}

\section{REFERENCES}

1. Adisasmita, Rahardjo. (2011). Manajemen Pemerintah Daerah. Yogyakarta: Graha Ilmu.

2. Kartika, Citrawati Fitri, et al. (2012). Good Environmental Governance. Malang: UB Press.

3. Mustafa, Delly. (2013). Birokrasi Pemerintahan. Bandung: Alfabeta.

4. Nasution. (2008). Manajemen Humas di Lembaga Pendidikan.

5. Pandiangan, Saut Maruli Tua. (2015). Analisis Lama Mencari Kerja Bagi Tenaga Kerja Terdidik di Kota Medan. Skripsi. Medan: Fakultas Ekonomi dan Bisnis, Program Studi Ekonomi Pembangunan, Universitas Sumatera Utara. https://www.academia.edu/52494724/Analis is_Lama_Mencari_Kerja_Bagi_Tenaga_Ker ja_Terdidik_di_Kota_Medan.

6. Pandiangan, Saut Maruli Tua. (2018). Analisis Faktor-faktor yang Mempengaruhi Penawaran Tenaga Kerja Lanjut Usia di Kota Medan. Tesis. Medan: Fakultas Ekonomi dan Bisnis, Program Studi Ilmu Ekonomi, Universitas Sumatera Utara. http://repositori.usu.ac.id/bitstream/handle/1 23456789/10033/167018013.pdf?sequence= $1 \&$ isAllowed $=\mathrm{y}$.
7. Pandiangan, Saut Maruli Tua, Rujiman, Rahmanta, Tanjung, Indra I., Darus, Muhammad Dhio, \& Ismawan, Agus. (2018). An Analysis on the Factors which Influence Offering the Elderly as Workers in Medan. IOSR Journal of Humanities and Social Science (IOSR-JHSS), 23(10), 76-79. DOI: 10.9790/0837-2310087679.

8. Pandiangan, Saut Maruli Tua, Resmawa, Ira Ningrum, Simanjuntak, Owen De Pinto, Sitompul, Pretty Naomi, \& Jefri, Riny. (2021). Effect of E-Satisfaction on Repurchase Intention in Shopee User Students. Budapest International Research and Critics Institute-Journal, 4(4), 77857791.

DOI: https://doi.org/10.33258/birci.v4i4.2697.

9. Prasetijo. (2009). Prinsip-Prinsip Dasar Good Corporate Governance. Jakarta: Total Media.

10. Santosa, Pandji. (2008). Administrasi Publik Teori dan Aplikasi Good Governance, Bandung: Refika Aditama.

11. Sinambela, Lijan Poltak. (2008). Reformasi Kebijakan Publik. Jakarta: PT Bumi Aksara.

12. Tobing, Murniati, Afifuddin, Sya'ad, Rahmanta, Huber, Sandra Rouli, Pandiangan, Saut Maruli Tua, \& Muda, Iskandar. (2018). An Analysis on the Factors Which Influence the Earnings of Micro and Small Business: Case at Blacksmith Metal Industry. Academic Journal of Economic Studies, 5(1), 17-23. https://www.ceeol.com/search/articledetail ?id=754945.

How to cite this article: Gusman D, Amin M, Siahaan AYS. Good governance in regional development in Deli Serdang Regency. International Journal of Research and Review. 2021; 8(12): 108-118. DOI: https://doi.org/ 10.52403/ijrr.20211215 